\title{
PROJEKT „TEOLOGII” EWOLUCYJNEJ EDWARDA D. COPE’A
}

\begin{abstract}
Streszczenie. Edward Dinker Cope (1840-1897) był jednym z najbardziej wpływowych przyrodników XIX wieku, który doprowadził do rozwoju amerykańskiej paleontologii oraz popularyzacji teorii ewolucji Lamarcka. Teorię tę rozwinął pod postacią autorskiej koncepcji psycholamarkizmu. Jednym z pomijanych wątków jego biografii są jego poglądy filozoficzne. Zdaniem Cope'a teologia naturalna powinna zostać zreformowana przez wprowadzenie do niej nowych założeń filozoficznych, zgodnych z formującą się nauką ewolucjonizmu. Cope proponował stworzenie nowej „teologii”, która miała się opierać na jego koncepcji ewolucji kierowanej świadomością, jak również doborem naturalnym. W artykule przeanalizowano filozoficzne propozycje Cope’a oraz ukazano, w jaki sposób zreinterpretował mechanizm selekcji, wpisując go w swoją teleologiczną wizję procesu ewolucyjnego. Zdaniem Cope’a człowiek, posiadając wolną wolę, jest w stanie kierować swoją ewolucją, lecz nie ma gwarancji tego, że będzie w stanie przetrwać. Teza ta miała charakter teologiczny w dziełach Cope’a, który w nieprzystosowaniu widział odpowiednik grzechu, a ten z kolei eliminowany był przez dobór naturalny. W ten sposób akceptacja Boga stawała się jedyną drogą gwarantującą przetrwanie. Jednak ta konkluzja doprowadziła Cope’a do racjonalizacji rasizmu, gdyż widział on w wyzysku innych ras skutki ich ewolucyjnej degeneracji. Poglądy Cope’a odzwierciedlają współczesne problemy, jakie można zauważyć w naukach społecznych, jeśli odwołują się do mechanizmu doboru naturalnego.
\end{abstract}

Słowa kluczowe: Edward Dinker Cope; ewolucja; Karol Darwin; neolamarkizm; zaćmienie darwinizmu

1. Wstęp. 2. Amerykańska szkoła neolamarkizmu. 3. Nowa „teologia” Edwarda D. Cope’a. 4. Rola doboru naturalnego w filozofii Cope’a na tle wiktoriańskich koncepcji „chrześcijańskiego ewolucjonizmu". 5. Wnioski.

\section{WSTĘP}

W 1872 roku Asa Gray wysłał do Karola Darwina list z informacją, że jeden z najwybitniejszych amerykańskich entomologów, Alepheus Packard, chciałby go poznać i pyta, czy Darwin nie mógłby go przyjąć. Jak wyjaśniał Darwinowi Gray, Packard był członkiem „szkoły 
Hyatta-Cope’a, o której zapewne słyszałeś - ludzi, którzy odkryli, jak twierdzą, prawo [ewolucji - M.W.]" (Gray 1893, 623-624). Darwin był już wtedy zaznajomiony z poglądami głównego przedstawiciela owej szkoły - Edwarda D. Cope'a. Po przeczytaniu jego artykułu On the Origin of Genera Darwin zwierzył się w liście z 1871 roku swojemu synowi Williamowi, że nie miał wielkiego mniemania na temat tez jego autora, który według niego „pisał bardzo niezrozumiale” (Darwin Correspondence Project 1871). Pomimo to, w szóstym wydaniu O porwstawaniu gatunków... (i w kolejnych) pojawia się wzmianka o osobie Cope'a i badaczach ze Stanów Zjednoczonych, którzy mieli zwracać uwagę na rolę, jaką odgrywa w procesach ewolucyjnych „przyśpieszenie lub opóźnienie okresu rozmnażania” (Darwin 1959, 186). Choć Darwin nie wchodził w dalszą dyskusję z poglądami szkoły Cope'a-Hyatta, Amerykanie dość szybko zareagowali na tę wzmiankę. W założonym i redagowanym przez Hyatta, Cope’a i Packarda piśmie The American Naturalist została opublikowana notka stwierdzająca, że Darwin zniekształcił poglądy szkoły amerykańskiej, i że ani Cope, ani jego zwolennicy nie zgadzają się z opublikowaną przez Darwina tezą (Z. 1872). W korespondencji Darwina z Hyattem (nawiązanej w 1871 roku) Darwin przeprosił za niedokładny opis poglądów Amerykanów, wyjaśniając: „nigdy nie byłem w stanie pojacć, co dokładnie chcecie przekazać (...)" (Darwin Correspondence Project 1872).

Pomimo niejasności poglądów szkoła Cope’a-Hyatta miała znaczący wpływ na amerykańską paleontologię, doprowadzając do wzrostu zainteresowania promowanym przez Cope'a neolamarkizmem (Hall 2002). Przyczyniła się do tego również wysoka pozycja Cope'a pośród paleontologów, który wraz z rywalizującym z nim Othnielem Charlesem Marshem doprowadził do odkrycia skamieniałości ponad półtora tysiąca wymarłych gatunków (Rainger 2009). W dużej mierze dzięki tej pracy Cope zapisał się na kartach historii biologii. Praca filozoficzna jest bardziej marginalizowanym aspektem biografii Cope’a. Znany był głównie jako zwolennik neolamarkizmu 
i z tego też powodu jego rozważania były traktowane jako jeden z przejawów tworzącej się pod koniec XIX wieku opozycji w stosunku do teorii Darwina. Na przykład zdaniem Ernsta Mayra Cope współtworzył mało rozwojowy z perspektywy współczesnej biologii nurt ewolucjonizmu, który mając bardziej charakter ideologiczny niż naukowy, skazany był na zapomnienie (Mayr 1982). Jednak współcześni historycy (np. Armon 2010) coraz częściej odchodzą od tego typu uproszczeń i próbują odtworzyć panujący w XIX wieku klimat ideowy, aby dzięki temu lepiej zrozumieć specyfikę rozwoju biologii w tamtym okresie. Postać Cope’a w tym kontekście wydaje się szczególnie interesująca ze względu na zagadnienie relacji między religią a ewolucjonizmem, która w historii nauki najczęściej traktowana była jako otwarcie antagonistyczna. Cope wyłamywał się z tego trendu, próbując stworzyć nową filozoficzną perspektywę, inną niż materializm i idealizm, która byłaby w stanie pogodzić światy nauki i wiary (Cope 1887b).

Artyku1 jest próbą syntetycznego scharakteryzowania filozofii Cope'a i ukazania jej w szerszym kontekście poglądów ewolucjonistycznych amerykańskiej szkoły neolamarkizmu, którą współtworzył. Filozoficzne stanowisko Cope'a zostanie również poddane analizie. Szczególna uwaga zostanie poświęcona relacji, jaka zachodziła między jego poglądami a darwinizmem, a zwłaszcza tym jego aspektem, który dotyczy inkorporacji mechanizmu doboru naturalnego. W rezultacie wyjaśnione zostanie, w jaki sposób Cope, promując teleologiczną i semikreacjonistyczną wizję ewolucji, wkomponował w nią teorię selekcji naturalnej.

\section{AMERYKAŃSKA SZKOŁA NEOLAMARKIZMU}

Jak stwierdzają współcześni historycy ewolucjonizmu, heterodoksja poglądów i rozbudowany „żargon Cope’a tworzył okultystyczną atmosferę charakterystyczną dla całej jego twórczości" (Moore 1979, 149), co sprawiało, że jego „filozofia rozwoju, była tak obca 
darwinizmowi, że byłoby praktycznie niemożliwe ujęcie jej w terminach zrozumiałych zarówno przez Darwina, jak i współczesnego czytelnika" (Bowler 1977, 251). Za hermetycznym językiem kryły się jednak poglądy dość rozpowszechnione wśród niedarwinowskich ewolucjonistów XIX wieku. Główną inspiracją dla poglądów Cope’a były prace Louisa Agassiza, a zwłaszcza jego teoria rekapitulacji. Zdaniem Agassiza zwierzęta należące do tego samego taksonu miały wykazywać podobieństwo form, jakie przybierały w trakcie swojego rozwoju osobniczego (Agassiz 1849). Idea ta, przeniesiona w kontekst teorii ewolucji, doprowadziła jego uczniów do wniosku, że rozwój ontogenetyczny determinuje filogenezę. Zdaniem Cope'a, obserwując zmiany, jakie przechodziły w trakcie swojego rozwoju osobniki, można wywnioskować, czy gatunek będzie dalej ewoluował, czy też ulegnie degeneracji (Cope 1887c). Podstawą tych przekonań była teza cykliczności ewolucji, którą Cope i Hyatt zaproponowali niezależnie od siebie (Hilton, Mitchell, Smith 2014), a zgodnie z którą gatunki miały wytwarzać nowe cechy pod wpływem praw akceleracji, co doprowadzało do ich rozwoju, oraz ulegać degeneracji, gdy siły ewolucyjne zaczynały słabnąć. Właśnie „prawo degeneracji i akceleracji siły wzrostu" (Cope 1868, 244) stało się centralną tezą założonej przez Cope'a i Hyatta szkoły. Prawo to łączyli oni w późniejszych latach z tezami Jean-Baptiste'a Lamarcka, stwierdzając, że kluczowymi mechanizmami przemian ewolucyjnych było używanie i nieużywanie narządów oraz dziedziczenie cech nabytych, sama zaś ewolucja była możliwa dzięki wewnętrznym siłom organizmu. Ten związek z lamarkizmem sprawił, że ich szkoła zyskała nazwę neolamarkowskiej, a oni sami uznali się za bezpośrednich kontynuatorów autora Filozofi zoologii (Hyatt 1884).

Mogłoby się wydawać, że synteza poglądów Agassiza i Lamarcka, której dokonali Cope i Hyatt, była wewnętrznie sprzeczna. Teoria rekapitulacji Agassiza nie powstała jako prawo ewolucyjne, a jako zasada taksonomiczna, zaś jej twórca był krytykiem lamarkizmu (Mayer 1911). Agassiz jako kreacjonista wychodził z założenia, że 
celem przyrodnika było zrozumienie planu boskiego stworzenia, zaś taksonomia miała ukazywać realne różnice między stworzonymi oddzielnie grupami zwierząt (Agassiz 1859). Amerykańscy neolamarkiści stwierdzali, że to ostatecznie dogmatyzm religijny nie pozwolił Agassizowi na akceptację ewolucjonizmu (Packard 1898). Zgadzali się z nim co do celów, jakie miało przed sobą stawiać przyrodoznawstwo. Jak pisał Packard, ostatecznym celem szkoły amerykańskiej było stworzenie nowej „teologii naturalnej” zgodnej z udowodnionym przez Darwina zjawiskiem ewolucji (Moore 1979). Te właśnie sentymenty kreacjonistyczne mogły być jednym z powodów, dla którego Amerykanie ostatecznie przyjęli Lamarcka jako jednego z patronów swojej szkoły. Jak zauważył Peter Bowler, popularność lamarkizmu w drugiej połowie XIX wieku można wyjaśnić po części tym, że pośród różnych funkcjonujących wówczas teorii konkurujących $z$ darwinizmem był on najbardziej kompatybilny $\mathrm{z}$ ideą boskiej kreacji, gdyż pozwalał interpretować ewolucjonizm w zgodzie z filozofią idealizmu i teleologizmem (Bowler 1992). Prace Cope'a, które Packard uznał za fundament całej szkoły amerykańskiego neolamarkizmu (Packard 1901), reprezentowały taką właśnie próbę pogodzenia idei kreacjonistycznych z ewolucjonizmem.

W 1871 roku Cope przedstawił swoją neolamarkowską teorię ewolucji w artykule The Method of Creation of Organic Forms, która później spopularyzował w książce The Origin of the Fittest: Essays on Evolution. Zdaniem Cope'a podstawowy problem teorii doboru naturalnego polegał na tym, że nie wyjaśniała ona sposobu, w jaki wytwarzają się nowe cechy przystosowawcze. Selekcja w formie, w jakiej zaprezentowali ją Darwin i Wallace, nie mogła mieć charakteru twórczego, gdyż jej funkcja ograniczała się jedynie do utrwalania wcześniej zaistniałych zmian w organizmach (Cope 1871). Należało więc pokazać, w jaki sposób tworzą się te nowe cechy. Po części zjawisko to tłumaczyły prawa akceleracji i degeneracji - określały one kolejno rozrost i zanikanie danych narządów (Cope 1887c). Rozwój narządów możliwy był dzięki immanentnej „sile wzrostu”, która była 
energią, jaką wytwarzał organizm w trakcie m.in. metabolizmu lub fotosyntezy. W zależności od tego, jak siła wzrostu była lokowana $\mathrm{w}$ danym organizmie, wytwarzała ona odpowiednie przemiany. $Z$ reguły sposób lokowania nie zmieniał się, a był przekazywany z pokolenia na pokolenie, co też doprowadzało do ujednolicenia się morfologii przedstawicieli tego samego gatunku. Aby więc mogło dojść do modyfikacji, organizm musiał zmienić sposób lokowania siły wzrostu. To z kolei było możliwe dzięki prawom używania i nieużywania narządów, zaproponowanym przez Lamarcka.

Osobniki zmieniając swoje nawyki, doprowadzały do przekształceń w swojej budowie, gdyż każda zmiana w używaniu narządów wiązała się z innym zagospodarowaniem siły wzrostu (Cope 1871). Cope bazował tu na pomyśle dziedziczenia pamięci autorstwa Ewalda Heringa (por. Cope 1904, 479-480; 1887c, 29; Hering 1913, 38). Hering odróżniał czynności oddziedziczone od nieoddziedziczonych, a różnica między nimi polegała na tym, że te pierwsze można było wykonywać w sposób nieświadomy. Jeżeli natomiast jakaś czynność wymagała większego skupienia, czyli wykonywana była w sposób świadomy, oznaczało to, że organizm dopiero uczył się jej. Częste powtarzanie takiej czynności pozwalało zmienić ją w nawyk, co oznaczało, że zapisywała się ona w strukturze organizmu i mogła być przekazana w procesie dziedziczenia. Stosując to rozróżnienie do procesów ewolucyjnych, Cope wysunął wniosek, że jeżeli miała zajść ewolucja gatunku, musiało wystąpić w nim świadome, wolitywne działanie przełamujące odziedziczone nawyki i zmieniające sposób lokowania siły wzrostu. Dlatego też ostatecznie to świadomość stanowiła w teorii Cope’a główny czynnik ewolucji. Gdy więc organizmy zrywały z odziedziczonymi nawykami, aby dostosować się do nowego środowiska, ich siła wzrostu ulegała akceleracji i doprowadzała do dalszej ewolucji. Jeżeli jednak tego nie robiły, ich świadomość zaczynała zanikać, a one same ulegały degeneracji (Cope 1887c). Same jednak próby dostosowania się nie gwarantowały organizmowi przetrwania. Jak zaznaczał Cope, walka o byt istniała i wygrywały 
ją organizmy, które były w stanie najlepiej dostosować się do środowiska. Dlatego też, jego zdaniem, nie powinno się mówić o selekcji naturalnej, a o selekcji inteligencji, gdyż dobór ostatecznie promował te organizmy, które były w stanie najlepiej nakierować swoją wolę na przetrwanie (Cope 1871).

Lamarkizm pozwolił Cope'owi na zachowanie elementów teleologicznych w jego teorii ewolucji. Kierunek ewolucji był uzależniony od starań samych organizmów, które na mocy praw Lamarcka mogły same wyznaczać drogę swojego rozwoju (Cope 1887c). Ze względu na to, że Cope podkreślał wolitywny charakter przemian gatunków, jego teoria zyskała miano psycholamarkizmu, choć on sam swoją koncepcję świadomej ewolucji wolał nazywać ,archesteizmem” (Cope 1887c, 418-419). I to właśnie na gruncie archesteizmu Cope zaczął budować nową „teologię ewolucjonizmu”, wypełniając tym samym cel, który postawił przed amerykańskimi ewolucjonistami Packard.

\section{NOWA „TEOLOGIA" EDWARDA D. COPE'A}

Cope pomimo tego, że zyskał wśród swoich współpracowników opinię uzdolnionego filozofa, czekał ponad dziesięć lat od momentu ogłoszenia swojej teorii psycholamarkizmu, aby przedstawić projekt „teologii” ewolucyjnej. Przez „teologię” powinno się w tym miejscu rozumieć nową wersję teologii naturalnej Williama Paley’a, w której stworzeniu Packard widział ostateczny cel badań neolamarkistów. Cope miał szanse stać się „nowym Paley'em”, lecz zwlekał z przedstawieniem światu swoich poglądów filozoficznych. Zwłoka ta wynikała po części z przyczyn osobistych. Cope wychował się w rodzinie kwakrów, a jego ojciec, od którego był uzależniony finansowo, nie pochwalał naukowych zainteresowań syna (Davidson 1997). Dopiero po śmierci ojca w 1875 roku, kiedy Cope opuścił Religijne Towarzystwo Przyjaciół na rzecz bardziej tolerancyjnego Kościoła Unitarnego, zdecydował się ujawnić światu swoje poglądy filozoficzne (Moore 
1979). W 1887 roku opublikował Theology of Evolution stanowiąca zarys jego filozofii.

Zdaniem Cope'a istniejący konflikt miedzy religią i nauką był czymś chwilowym i miał zostać rozwiązany wraz z rozwojem wiedzy. Jednak pogodzenie tych dwóch sfer musiało nieść za sobą reformę teologii - musiała zostać zbudowana od nowa, na nowych podstawach filozoficznych, a dokładniej na dwóch doktrynach: ewolucjonizmu i realizmu. Przez doktrynę ewolucjonizmu Cope rozumiał tu własny pomysł archesteizmu, który wyjaśniał powstanie zarówno życia organicznego, jak i duchowego. Przez realizm natomiast rozumiał scjentyzm, przeciwstawiając go idealizmowi i twierdząc, że wszelkie zasady rządzące rzeczywistością udawało się odkryć dzięki naukom szczegółowym. W tym sensie można określić Cope’a jako umiarkowanego materialistę, co jednak nie oznacza, że był redukcjonistą. Jak twierdził, jedną z największych filozoficznych przeszkód $\mathrm{w}$ pogodzeniu religii $\mathrm{z}$ nauką był skrajny determinizm promowany $\mathrm{w}$ obecnym przyrodoznawstwie. Determinizm ten zakładał, że umysł, będąc jedynie funkcją materii ożywionej, nie może dokonywać aktów wolnej woli, gdyż każda jego czynność jest zdeterminowana przez działanie organizmu. Zdaniem Cope'a taki pogląd negował istnienie Boga. Zarzut ten opierał się na jego koncepcji neolamarkowskiej. Cope, widząc w Bogu „Najwyższy Rozum”, stwierdzał, że gdy determiniści odmawiali organizmom świadomości, musieli w konsekwencji zaprzeczać możliwości istnienia jakiekolwiek świadomości w przyrodzie, w tym też tej Najwyższej (Cope 1875). Sam fakt kontroli umysłu nad materią wskazywał, że we wszechświecie musiało funkcjonować coś „ekstra mechanicznego” (Cope 1893, 629). Czyli istnienie ograniczonego umysłu zwierzęcego wskazywało na istnienie nieograniczonego umysłu Boskiego.

Jak później doprecyzował, Bogiem była pierwsza świadomość, która popchnęła materię do rozwoju, a która obecnie przejawia się we wszystkich ewoluujących gatunkach (Cope 1893). Na istnienie Boskiego źródła ewolucji wskazywała również psychologia. Cope 
argumentował, że skoro w ludziach istnieją uczucia, takie jak miłość i altruizm, które nie mogły powstać w sposób naturalny, gdyż zaprzeczałoby to prawu walki o byt, to ich źródło musiało pochodzić od tej nadnaturalnej Boskiej świadomości. Nie dość więc, że ewolucja miała swój początek w Boskim Stwórcy, to fakt, iż nadał on ludziom uczucia, wskazywał na to, że sam był zdolny do odczuwania (Cope 1889). Ta koncepcja „Bóstwa ewolucji” (Cope 1893, 635) miała być ostatecznym rozwiązaniem sporów między ateizmem materialistów, a antyscjentyzmem idealistów. Ewolucjonizm stanowił więc dla Cope’a złoty środek, który miał połączyć te prądy filozoficzne, tworząc nową „teologię”. Tym samym Cope był przekonany, że udało mu się znaleźć naukowy argument za istnieniem Boga: „(...) dokonaliśmy tego, co jak twierdził Hiob, nie mogło być dokonane; dosłownie szukając, udało się nam odnaleźć Boga" (Cope 1875, 28).

Sprzeciw Cope’a wobec skrajnego determinizmu był również zauważalny w jego poglądach antropologicznych. Człowiek był dla niego najwyżej rozwiniętym organizmem, gdyż najlepiej zapanował nad lokowaniem siły wzrostu, doprowadzając do tego, że był w stanie kontrolować swoje środowisko (Cope 1904). Jednak w przeciwieństwie do innych teistycznych ewolucjonistów Cope nie uważał, że ta pozycja człowieka była wynikiem boskiej interwencji. Jak twierdził, poglądy kreacjonistów wierzących w boski interwencjonizm stanowiły antyfilozofię, według której człowiek nie był w stanie samodzielnie wykształcić narzędzia potrzebne do przetrwania (Cope 1887c). Człowiek sam doprowadził do rozwoju swego umysłu na drodze praw używania i nieużywania narządów, i dzięki własnym staraniom wyniósł się ponad swe zwierzęce dziedzictwo, wchodząc na nowy szczebel ewolucji (Cope 1875). Ten rozwój zawdzięczał nauce i technice, dzięki którym był w stanie opanować prawa akceleracji i użyć ich na swoją korzyść (Cope 1887c). Jednak postulat ten miał pewne pesymistyczne konotacje. O ile w necesytarystycznej filozofii status człowieka był niepodważalny, gdyż był on częścią boskiego planu, to w archesteizmie mógł się w każdej chwili zmienić. Jak twierdził 
Cope, moralność, podobnie jak każde inne przystosowanie, powstała w wyniku świadomego działania, które zmieniło się w nieświadomy nawyk kształtujący gatunek ludzki. Analogicznie więc do innych adaptacji, ludzie pozbawieni nacisku pobudzającego ich do rozwoju moralności ulegali demoralizacji. Wysoka moralność była więc jednym z przejawów świadomego, inteligentnego działania. Jeżeli więc ewolucja polegała na tym, że gatunki były w stanie rozpoznać źródło swego cierpienia i go unikać, to demoralizacja oznaczała, iż traciły one tą zdolność. Dlatego też demoralizację należało uznać za objaw degeneracji gatunku (Cope 1875).

W tym miejscu warto zaznaczyć, że Cope utożsamiał zło moralne z cierpieniem wynikającym z nieprzystosowania. Dochodził więc do wniosku, że zło było z natury autodestrukcyjne, gdyż zawsze musiało zginąć w trakcie doboru naturalnego. Przenosząc to w kontekst etyki chrześcijańskiej, należało więc uznać grzech za degeneratywne skłonności człowieka, które musiał przezwyciężyć dzięki swojej woli. Cope wyjaśniał ten związek metaforą biblijną. Bóg tworzący Ziemię w sześć dni był, według niego, alegorią wszystkich naturalnych przemian, które doprowadziły do powstania gatunku ludzkiego. O wyjątkowości człowieka stanowiła jednak wolna wola, co w filozofii Cope’a oznaczało możliwość wyboru między hedonistycznym życiem zwierzęcia a moralnym życiem istoty, która porzuciła hedonizm na rzecz wyższych, intelektualnych wartości. Siódmy dzień, w którym Bóg odpoczywał po stworzeniu świata, był dla Cope’a metaforą tego, że świat nie był do końca zdeterminowany przez rządzące nim prawa, a istniało w nim miejsce dla wyboru własnej ścieżki ewolucyjnej. Wybór, przed jakim stał człowiek, obrazowała biblijna scena, w której pierwsi ludzie byli kuszeni przez węża do zjedzenia zakazanego owocu $z$,drzewa poznania dobra i zła”. Dla Cope’a była to metafora specyfiki istoty ludzkiej, w której mieszają się sprzeczne ze sobą potrzeby pochodzące od jego zwierzęcych przodków i te nadane przez Boga. Człowiek zrywający owoc symbolizował tu oddanie się swojej zwierzęcej stronie (Cope 1887c). Cope uzasadniał swoje odczytanie 
Księgi Rodzaju, powołując się na interpretację Adama Clarke’a, który w swoim komentarzu do Biblii sugerował, że słowo „wąż” powinno być rozumiane jako „małpa” (Clarke 1839). To dla Cope'a stanowiło dowód potwierdzający jego intuicję, że zwierzęce dziedzictwo człowieka jest przyczyną zła istniejącego na świecie i ono właśnie musi zostać przezwyciężone $\mathrm{w}$ trakcie ewolucji. W podobny sposób Cope interpretował wolną wolę - Bóg dał człowiekowi możliwość osiągnięcia doskonałości, ale on może ją zawsze odrzucić, skazując się na zagładę (Cope 1887c).

Aby nie dopuścić do degeneracji, potrzebne jest coś, co może ją zatrzymać i wspomóc rozwój moralności. Funkcję tę spełnia religia, a w szczególności chrześcijaństwo stanowiące jej najwyższą formę. Wyjątkowość chrześcijaństwa na tle innych religii potwierdzały, zdaniem Cope'a, dane historyczne. Argumentował, że etyka starożytnych Rzymian, Greków czy nawet narodu żydowskiego dopuszczała poziom barbarzyństwa, który byłby nie do przyjęcia wśród współczesnych chrześcijan. Wśród narodów, które nie przyjęły chrześcijaństwa, zauważalny był poziom demoralizacji oznaczający początki retrogresji i zezwierzęcenia. Aby więc cywilizacja mogła się dalej rozwijać potrzebna była jej religia, która odpowiednio nakierowałaby proces ewolucji (Cope 1887c). Rozpoznanie znaczenia religii dla rozwoju ludzkości - czyli wykształcenie w człowieku „wrażliwości religijnej” (Cope 1887c, 171) - stawało się w jego koncepcji cechą przystosowawczą. To religia pozwalała człowiekowi rozpoznać drogę rozwoju, którą wyznaczył mu Bóg, utrzymywać w harmonii jego zwierzęcą i boską naturę oraz wzmagać rozwój moralności. Ostatecznie więc to dzięki religii, a dokładniej chrześcijaństwu, możliwa była dalsza ewolucja ludzkości. I w rozpoznaniu wagi religii dla ewolucji Cope widział najważniejszy argument, który miałby przekonać ateistów do nawrócenia się (Cope 1887c). Biologia stawała się w jego pracach również apologetyką. Obrona chrześcijaństwa miała swoje podstawy empiryczne i wymiar praktyczny, gdyż dzięki uznaniu jej religijnego przewodnictwa „(...) możliwe staje się życie w zaawansowanej i stale 
postępującej doskonałości moralnej, a człowiek zbliża się do obrazu Boga" (Cope 1887c, 171).

\section{ROLA DOBORU NATURALNEGO W FILOZOFII COPE'A NA TLE WIKTORIAŃSKICH KONCEPCJI „CHRZEŚCIJAŃSKIEGO EWOLUCJONIZMU"}

Specyfika argumentacji Cope'a wpisuje się w szerszy nurt myśli ewolucyjnej, który Bowler nazywa „ewolucjonizmem rozwojowym”. W kontekście tego nurtu zakładano, iż procesy ewolucyjne polegają na udoskonalaniu się gatunków, które, podobnie jak w ontogenezie, przechodziły przez jasno rozróżnialne etapy. W naukach społecznych wpływ „ewolucjonizmu rozwojowego” zauważalny był w modelach historiozoficznych, w których zakładano, iż wszystkie społeczeństwa o niższym stopniu rozwoju kulturowego niż cywilizacja europejska reprezentowały wczesne fazy ewolucji ludzkości, stanowiąc tym samym swoiste „żywe skamieliny” (Bowler 1988). Podobne wpływy zauważalne są również u Cope’a. Gdy pisze on o „dzikości”, traktuje ją jako rudyment ewolucji kulturowej, zaś społeczności charakteryzujące się nią - jako stojące niżej w rozwoju niż cywilizacja zachodnioeuropejska ${ }^{1}$. W podobny sposób argumentuje on również wyższość chrześcijaństwa nad innymi religiami. Cope wiąże rozwój religii z typami ludzkimi, które pojawiają się w trakcie ontogenezy. Wyróżnia: typ dziecięcy, będący najbardziej prymitywnym; typ kobiecy, który wiąże $z$ adolescencją; oraz typ męski, odpowiadający dorosłości, który wiąże się z racjonalnością. Najdoskonalszym typem religii jest ten, który odpowiada typowi trzeciemu, czyli oparty jest na intelekcie. Cope nie pisze wprost, że chrześcijaństwo jako jedyne

1 U Cope’a „dzikość” nie objawia się jedynie na poziomie kulturowym, ale również morfologicznym. Dzikie narody wyróżniają się cechami fizycznymi, które są niespotykane wśród narodów bardziej rozwiniętych. Do takich nierozwiniętych ras należą np. Afrykanie i Słowianie (Cope 1887). 
reprezentuje ten typ, ale jednocześnie zaznacza, iż „pierwsze chrześcijańskie społeczeństwo wykazuje najbardziej doskonały stan rzeczy" (Cope 1887c, 166).

Jednak pomimo wyraźnych związków Cope’a z „ewolucjonizmem rozwojowym" nie można w pełni zgodzić się z Bowlerem, że poglądy twórcy archesteizmu formowały się w zupełnej izolacji od darwinizmu. Bowler w swoich pracach podkreśla sprzeciw Cope’a wobec doboru naturalnego (Bowler 1977), widząc w nim jednego z czołowych przedstawicieli tradycji „rozwojowej” (Bowler 1988). Jednak w pracach samego Cope’a (jak i innych neolamarkistów) można zauważyć, że dobór odgrywał ważną rolę, nawet jeżeli ograniczał się jedynie do mechanizmu eliminacji organizmów nieprzystosowanych. Na tym też polegała główna różnica między nim a Lamarckiem. Cope zakładał, że organizm pomimo swoich starań może nie przystosować się do środowiska. Sama walka o przetrwanie wzmacniała według niego procesy używania i nieużywania narządów, zmuszając organizmy do kształtowania odpowiednich cech (Cope 1875). Biograf i uczeń Cope'a, Henry Osborn, odnotowuje, że był on darwinistą jeszcze w 1871 roku, czyli gdy formował swoje najważniejsze koncepcje ewolucyjne (Osborn 1929). Wbrew tezie Bowlera istnieją więc argumenty za tym, że darwinizm wpłynął na kształtowanie się filozofii Cope'a, co może wyjaśniać, dlaczego w swoich pracach odwoływał się nadal do doboru naturalnego pomimo zaproponowania innych mechanizmów ewolucyjnych. Teizm ewolucyjny Cope’a wraz z jego ideą teleologicznego rozwoju powstawał w oparciu o ideę „walki o byt”.

Jak zauważa James R. Moore, teiści promowali ideę progresywnego, teleologicznego procesu ewolucyjnego po to, aby przeciwdziałać relatywizującym konotacjom darwinowskiej ewolucji, która ostatecznie nie zgadzała się z chrześcijańską teodyceą. Widzieli w ewolucji proces dążący do stworzenia coraz doskonalszych form istnienia, zaś dobór traktowany był przez nich jako konieczny środek do ich kreacji (Moore 1979). Możliwość pogodzenia tych dwóch, zdawałoby się sprzecznych, idei - nieprzewidywalności ewolucji z finalizmem 
promowanym przez teistów - wynikała ze specyfiki samej teorii Darwina. Ewolucjonizm Darwina mógł być interpretowany przez pryzmat teleologii, gdyż on sam formułował swoją teorię $\mathrm{w}$ taki sposób, aby ukazać istnienie celowości w powstających narządach. Ten utylitarystyczny charakter darwinizmu nakierowywał interpretatorów na teleologizm, ponieważ interpretując budowę organizmu przez pryzmat jego przystosowania, można było wnosić o istnieniu pewnego celu, dla którego powstał.

Obecnie uważa się, że teoria Darwina nie miała charakteru teleologicznego, a teleonomiczny, aczkolwiek biorąc pod uwagę, że termin ten powstał dopiero w XX wieku, używanie go na określenie darwinizmu jest anachronizmem. Pomijając jednak kwestie terminologiczne, należy podkreślić, że Darwin, nawet jeżeli używał języka teleologicznego, robił to w specyficzny sposób. Dobrze obrazuje to metafora, której używał, tłumacząc "celowy” charakter działania doboru: „Fragmenty skały spadające $z$ wysokiej przepaści przybierają nieskończoną liczbę kształtów - kształty te wynikają z natury skały, prawa grawitacji itd. - po prostu wybierając dobrze ukształtowane kamienie i odrzucając źle ukształtowane, architekt zwany Naturalną Selekcją może stworzyć w ten sposób wiele różnych i doskonałych budynków" (Burkhardt, Secord, et al. 1999, 672). Opis Darwina wskazuje jasno, że istnieją determinanty, które doprowadzają do powstania porządku w przyrodzie, lecz związki między nimi nie tworzą prostego łańcucha przyczynowoskutkowego. Tak specyficznie rozumiana celowość wystarczała filozofom chrześcijańskim, aby pogodzić dobór z ideą celowości. Istniał więc pewien ostateczny cel ewolucji, który należało rozumieć jako obecny porządek przyrody, zaś dobór naturalny interpretowany był jako zbiór wszystkich przyczyn, które doprowadziły do jego powstania (Moore 1979). Warto w tym miejscu zaznaczyć, że ten sposób rozpoznawania celowości w przygodnych przyczynach był już znany w teologii naturalnej. William Paley tłumaczył następująco: „W stworzeniu musi być przypadek; przez co rozumiemy, że wydarzenia, które nie są zaprojektowane, 
muszą koniecznie wynikać z dążenia do wydarzeń, które są zaprojektowane" (Paley 1852, 330). Można było więc akceptować przygodny charakter przemian ewolucyjnych, o ile uznawało się, że prowadziły one do pewnej niezmiennej stałej, jaką był np. obecny stan przyrody. U Cope’a wątek konieczności teraźniejszego stanu rzeczy najbardziej przejawiał się $\mathrm{w}$ sposobie, $\mathrm{w}$ jaki stosował archesteizm $\mathrm{w}$ filozofii społecznej.

Archesteizm Cope’a tworzył specyficzną wizję historiozoficzną, która wyróżniała się na tle innych koncepcji ewolucji społecznej powstałych w XIX wieku. Większość historiozofów akceptowała liniową, progresywną wizję przemian kulturowych, zaś Cope przekonywał, że zmiany cywilizacyjne przebiegają w sposób cykliczny. Wraz z rozwojem technologicznym i ekonomicznym społeczeństwom zaczynało brakować impulsów pobudzających dalszą ewolucję moralną. Zaczynał szerzyć się hedonizm, a wraz z nim postępowała degeneracja. Powstałe w ten sposób hedonistyczne społeczeństwo stawało się ofiarą doboru naturalnego, gdyż w każdej chwili mogło być zajęte przez wrogie siły (Cope 1887c). Podobnie, zdaniem Cope'a, wyglądał rozwój indywidualny. Jeżeli ludzie żyli w zbyt dużym luksusie, zaczynało im brakować impulsów do zmian, co też prowadziło do degeneracji. Cierpienie stawało się więc kluczowym elementem filozofii Cope'a, zaś walka o przetrwanie racją dostateczną do zachodzenia ewolucji. Dlatego też, jak pisał, w swoim rozwoju człowiek musi pozostawać egoistą walczącym o zasoby, gdyż konkurencja jest jednym z głównych impulsów ewolucyjnych, przy czym musi ją jednocześnie równoważyć $\mathrm{z}$ rozwojem moralnym (Cope 1871). Cope wprost stwierdzał, że największe osiągnięcia ludzkości, jak sztuka i nauka, powstały pod wpływem konfliktów. Wyrażał przy tym zaniepokojenie stanem Ameryki, która nie obawiając się wojen, straci impulsy do dalszego rozwoju (Cope 1892).

W tym miejscu należy jednak zauważyć, że - w przeciwieństwie do nieprzewidywalnego charakteru działania walki o byt w klasycznym darwinizmie - u Cope’a wynik doboru był znany. W końcu 
zawsze wygrywały jednostki, które lepiej zarządzały lokowaniem siły, posiadając większą świadomość i inteligencję. To z kolei otwierało w jego filozofii możliwość hierarchizowania ludzi. Jak pisał, ludzie nie są równi, gdyż posiadają różne stopnie inteligencji i mają tym samym różne predyspozycje do dalszego rozwoju (Cope 1871). Pogląd ten doprowadził Cope'a do normalizacji rasizmu i kolonializmu jako naturalnych konsekwencji procesu ewolucji. Krytykował on ruch sufrażystek i zniesienie niewolnictwa jako działania polityczne występujące przeciw naturze. Pomimo swoich ewolucjonistycznych poglądów twierdził, że pewne cechy mają charakter permanentny. Dlatego Afroamerykanin, jako przedstawiciel mniej rozwiniętej rasy, nigdy nie będzie w stanie osiągnąć tego samego stopnia rozwoju, co człowiek biały, a jego integracja może wręcz zaszkodzić dalszemu rozwojowi społeczeństwa amerykańskiego (Cope 1890). Podobnie upadek cywilizacji rdzennych Amerykanów nie był spowodowany przez agresywny ekspansjonizm Europejczyków, a był wynikiem degeneracji, zezwierzęcenia Indian, którzy poddali się pod władanie bardziej rozwiniętej kulturze kolonizatorów (Cope 1887c). Jak pisał Bowler, za te implikacje rasistowskie odpowiedzialny był lamarkizm, który postulując istnienie wielkiego łańcucha bytu, pozwalał na hierarchizowanie ludzi i z tego też powodu był częściej akceptowany przez naturalistów o bardziej konserwatywnym światopoglądzie (Bowler 1992). Podkreślana przez Cope’a konieczność konkurencji oraz naturalność wyzysku i cierpienia nie świadczy jednak stricte o inspiracjach lamarkizmem, który nie zakładał „przetrwania najlepiej dostosowanych". Dla porównania, inspirowana lamarkizmem filozofia społeczna, która promowana była w XIX-wiecznej Francji, opierała się jedynie na tzw. eugenice pozytywnej. Konkurencja nie była ważna dla eugeników lamarkowskich. Głosili oni raczej ideę pracy u podstaw, wskazując na konieczność powszechnej edukacji, dzięki której społeczeństwo nabywałoby konieczne do udoskonalenia cechy (Popowicz 2009). Jeżeli więc nawet zgodzimy się z Bowlerem, że rasizm Cope’a miał swoje źródło w lamarkizmie, to należy również 
dodać, iż jego przekonanie o konieczności wymierania "gorszych” ras miało swe źródło w teorii doboru naturalnego.

Trzeba podkreślić, że teoria doboru naturalnego nie musi suponować promocji postaw elitarystycznych, czego przykładem jest sam Darwin, który był zwolennikiem abolicjonizmu. Aczkolwiek stosowanie teorii Darwina do nauk społecznych rzadziej spotyka się z akceptacją osób o poglądach egalitarnych, co dobrze obrazują współczesne kontrowersje wokół psychologii ewolucyjnej. Szukając przyczyn krytyki, jaka spotyka psychologię ewolucyjną, Peter Jonason i David P. Schmitt przeprowadzili badania, które miały na celu zidentyfikowanie źródeł i przyczyn odrzucenia lub akceptacji darwinizmu w środowiskach akademickich. Badania te ukazały dość ciekawą dychotomię. Jak się okazało, badani, którzy mieli wyższą orientację na dominację społeczną, wykazywali mniejszą krytyczność w stosunku do psychologii ewolucyjnej. Podobna korelacja wystąpiła wśród badanych o poglądach autorytarnych. Co ciekawe, w tych samych badaniach respondenci byli sceptyczni wobec biologii ewolucyjnej, widząc ją jako zagrożenie dla swoich poglądów religijnych (Jonason, Schmitt 2016). Dualizm tych wyników pokazuje uniwersalność darwinizmu jako argumentu w konfliktach społecznych. Historycznie zauważamy z jednej strony wykorzystywanie ewolucjonizmu jako naukowego argumentu za koniecznością reform społecznych w XIX wieku (zwłaszcza wśród polskich socjalistów; Popławski 2007), z drugiej strony zaś mamy współczesny sprzeciw środowisk liberalnych wobec socjobiologii i psychologii ewolucyjnej, postrzeganych jako naukowy argument za konserwatyzmem. Jądro krytyki liberalnej wobec zastosowania darwinizmu w naukach społecznych Edward Hagen sprowadza do następującego argumentu: „Psycholodzy ewolucyjni twierdzą, że ludzie mają wrodzoną i niezmienną naturę, więc muszą sprzeciwiać się zmianom społecznym lub politycznym i jedynie próbują naukowo uzasadnić status quo" (Hagen 2005, 170). Oczywiście jest to spore uproszczenie wysuwanej krytyki, lecz dobrze podsumowuje tę cechę darwinizmu, która może wydać się atrakcyjna 
dla myślicieli promujących poglądy elitarystyczne. Ponieważ darwinizm za cel stawia sobie wyjaśnienie pochodzenia współczesnej bioróżnorodności przez wskazanie na cechy adaptacyjne, które pozwoliły organizmom utrzymać się w walce o byt, to analogicznie obecny porządek społeczny może być również potraktowany jako wynik działania doboru naturalnego. Problem polega jednak na tym, że wszystkie przejawy życia społecznego mogą zostać potraktowane jako adaptacyjne. To $z$ kolei sprawia, że zachowania niemoralne (np. gwałt) mogą zostać ocenione jako korzystne przystosowawczo, gdyż gdyby takie nie były, zostałyby wyeliminowane przez dobór. W ten też sposób stają się one akceptowalne w kontekście biologicznym (Wilson, Dietrich, Clark 2003). W przypadku Cope'a mamy do czynienia z takim właśnie założeniem - uzasadniał on naturalność kolonializmu czy nierówności społecznych. Traktował je jako coś akceptowalnego, bo, w jego przekonaniu, wynikały z działania sił ewolucyjnych. Etyka, będąc wynikiem przystosowania, nie była dla Cope'a tylko zbiorem arbitralnie ustanowionych reguł, ale stanowiła wytworzone na drodze ewolucji zasady regulujące relacje międzyludzkie. Prawa człowieka były zaś przez niego definiowane jako „(...) prawo do podążania kursem progresywnej ewolucji bez zakłócenia przez niepotrzebne przeszkody" (Cope 1896, 4897). U Cope'a moralność i ewolucja były więc ze sobą silnie skorelowane, co sprawia, że jego rozważania są bardziej problematyczne pod względem etycznym niż np. współczesnych socjobiologów.

Specyfikę historiozoficznych rozważań Cope’a najlepiej ukazuje prochrześcijańska narracja, którą stosował w swoich pracach. Jest ona kumulacją i jednocześnie dobrą reprezentacją sposobów, w jakie XIXwieczni naturaliści interpretowali dobór naturalny. $Z$ jednej strony chrześcijaństwo przedstawione jest jako zwieńczenie progresywnego, analogicznego do ontogenezy procesu ewolucyjnego. Stanowi tym samym najdoskonalszy przejaw religijności. $Z$ drugiej strony zaś, Cope argumentując za jego doskonałością, porównuje współczesne narody chrześcijańskie do przeszłych społeczności wyznających inne 
religie, podkreślając zarówno przewagę moralności chrześcijańskiej, jak i fakt, że narody niechrześcijańskie uległy zagładzie właśnie przez swoją demoralizację (Cope 1887c). Chrześcijaństwo staje się zwieńczeniem, do którego prowadziła ewolucyjna walka o byt. W ten sposób działalność z założenia nieprzewidywalnego doboru zostaje ukazana jako celowa, gdyż prowadziła do ustanowienia obecnego status quo, który charakteryzuje się dominacją religii chrześcijańskiej. W oparciu o podobną logikę interpretowany jest wyzysk mniej rozwiniętych kultur. Teraźniejszość widziana jako finalny proces ewolucji retroaktywnie wyjaśnia przygodny charakter zmian zachodzących w trakcie działania doboru naturalnego, gdyż prowadzą one do powstania obecnego status quo. Mamy więc tu odzwierciedlenie myślenia Paley'a - niezaprojektowane zdarzenia tworzą zdarzenie zaprojektowane. W konsekwencji jednak Cope uzasadnia nierówności społeczne, traktując je jako konieczny produkt ewolucji. W ten też sposób progresywizm i selekcjonizm w jego myśli tworzą specyficzną wizję ewolucji jako procesu teleologicznego.

\section{WNIOSKI}

Ze współczesnej perspektywy filozoficznej poglądy Cope’a trudno uznać za odkrywcze, a nawet dobrze uargumentowane. Filozofia Cope’a oprócz tego, że bazuje na niepoprawnej koncepcji dziedziczenia i rozwijania cech przystosowawczych, przedstawia również mało satysfakcjonującą wizję relacji Boga do świata. Bóg Cope’a pomimo tego, że wyrzekał się on interwencjonizmu, jest ostatecznie „bogiem luk", służącym w jego filozofii do wytłumaczenia takich problematycznych zagadnień, jak powstanie świadomości czy pojawienie się życia na Ziemi. Podobnie problematyczna jest jego argumentacja na rzecz wyższości chrześcijaństwa nad innymi religiami, a także normalizacja rasizmu i ksenofobii. Cope w tych przypadkach popełnia błąd naturalistyczny, traktując zastany porządek społeczny jako 
moralnie pożądany jedynie ze względu na to, iż był on wynikiem działania praw przyrody.

Natomiast analizując rzecz z perspektywy historycznej, Cope jest ciekawą postacią, która podważa dwie dość rozpowszechnione hipotezy na temat teistycznych interpretacji ewolucjonizmu. Pierwszą z nich jest hipoteza Bowlera, iż były one dokonywane w kontekście idealizmu. Cope jednak wprost odrzucał idealizm, widząc w scjentyzmie i umiarkowanym materializmie bardziej odpowiedni kontekst, w którym mógłby tworzyć swoją nową ,teologię" (Cope 1887a). Jest to o tyle zaskakujące, że w klasycznych interpretacjach historii ewolucjonizmu antydarwinistyczne teorie $\mathrm{z}$ reguły traktowane były jako wyraz sprzeciwu wobec materializmu i scjentyzmu darwinowskiego (np. Mayr 1982). Podobnie koncepcja Cope’a podważa rozpowszechniony pogląd o negatywnym stosunku chrześcijańskich naukowców do ewolucjonizmu. Na łamach The American Naturalist Cope wraz z Packardem wprost bronili ewolucjonizmu przed zarzutami o ateizm, widząc w nim wręcz afirmację poglądów teistycznych (Cope, Packard 1886).

Kolejny ciekawy aspekt filozofii Cope'a związany jest z jego stosunkiem do darwinizmu. W klasycznej historiografii naukowej (czyli proponowanej przez Bowlera i Mayra) neolamarkiści amerykańscy traktowani byli jako zagorzali przeciwnicy selekcjonizmu. Jak wspomniano wcześniej, Cope nie tworzył swojej koncepcji w całkowitej izolacji od darwinizmu. Wprawdzie wchodził z nim w polemikę, ale jednak teoria doboru naturalnego pełniła ważną rolę w jego koncepcji, co najlepiej jest widoczne w jego filozofii społecznej i projekcie nowej „teologii”. W nowej „teologii” Cope’a dobór odzwierciedlał fakt, iż Bóg dał człowiekowi wolną wolę, aby ten mógł pokierować swoim przeznaczeniem, wybierając między demoralizacją i wyginięciem, a rozwojem moralnym i ewolucją. Dzięki inkorporacji mechanizmu selekcji do poglądów filozoficznych Cope unikał więc krytykowanego przez siebie skrajnego determinizmu. Co warto podkreślić, w tym zakresie poglądy Cope’a zbliżały się do poglądów Darwina na temat 
wolnej woli. Jak zauważył Ricardo Noguera-Solano, Darwin również odrzucał ideę predestynacji, ponieważ chciał zachować koncepcję wolnej woli i wizję Boga jako dobrego Stwórcy (Noguera-Solano 2013, 868-870).

O ile u Darwina nieprzewidywalność doboru sprawiała, że odrzucał on istnienie wielkiego łańcucha bytu, to w filozofii Cope'a taka hierarchizacja organizmów była możliwa. Po części wynikało to z wpływu paradygmatu „ewolucjonizmu rozwojowego”, o którym pisał Bowler. Założenie to posłużyło Cope’owi do racjonalizacji i głoszenia ksenofobicznych i rasistowskich poglądów. Jak wspomniano jednak wcześniej, sam paradygmat „rozwojowy” nie był w pełni odpowiedzialny za tę kontrowersyjną stronę filozofii Cope'a. Ostatecznie to idea selekcji jako powszechnego mechanizmu działania przyrody stanowiła najważniejszy argument za normalizacją wyzysku i dyskryminacji ludzi, których Cope traktował jako „gorzej” rozwiniętych. Dobór naturalny u Cope’a służył jako usprawiedliwienie istniejących nierówności społecznych, które były przez niego rozumiane jako naturalny wynik działania procesów ewolucyjnych. Taki sposób zastosowania tej koncepcji ukazuje zagrożenie, jakie wiąże się ze stosowaniem mechanizmu doboru naturalnego w naukach społecznych, na co obecnie zwracają uwagę krytycy psychologii ewolucyjnej.

\section{BIBLIOGRAFIA}

Agassiz, L. (1849). Lectures on comparative embryology, delivered before The Lowell Institute, in Boston, December and January, 1848-9. Boston: Henrz Flanders. Agassiz, L. (1859). An essay on classification, London: Longman, Brown, Green, Longmans and Roberts and Trubner.

Armon, R. (2010). Beyond Darwinism's Eclipse: Functional Evolution, Biochemical Recapitulation and Spencerian Emergence in the 1920s and 1930s. Journal for General Philosophy of Science, 41, 173-194.

Bowler, P.J. (1977). Edward Drinker Cope and the Changing Structure of Evolutionary Theory. Isis, 2(68), 249-265. 
Bowler, P.J. (1988). The non-Darwinian revolution. Reinterpreting a historical myth, Baltimore - London: The Johns Hopkins University Press.

Bowler, P.J. (1992). The eclipse of Darwinism. Anti-Darwinian evolution theories in the decades around 1900. Baltimore - London: The John Hopkins University Press.

Burkhardt, F., Porter, D., Dean, S.A., Topham, J.R., Wilmot, S. (1999). The Correspondence of Charles Darwin, Vol. 11. Cambridge: Cambridge University Press.

Clarke, A. (1839). The Holy Bible. Containing The Old And New Testaments. Vol. 1. London: William Tegg.

Cope, E.D. (1871). The Method of Creation of Organic Forms. Proceedings of the American Philosophical Society, 12(86), 229-263.

Cope, E.D. (1875). Theology of Evolution. A Lecture. Philadelphia: Arnold and Company.

Cope, E.D. (1887a). Psychology. The American Naturalist, 6(21), 594-595.

Cope, E.D. (1887b). Psychology. The American Naturalist, 10(21), 948-951.

Cope, E.D. (1887c). The Origin of the Fittest: Essays on Evolution. New York: D. Appleton and Company.

Cope, E.D. (1889). Ethical Evolution. The Open Court, 82(3), 1523-1525.

Cope, E.D. (1890). Two Perils of the Indo-European. The Open Court, 48(126), 2052-2054.

Cope, E.D. (1892). The Future of Thought in America. The Monist, 1(3), 23-29.

Cope, E.D. (1893). The Foundation of Theism. The Monist, 3(4), 623-639.

Cope, E.D. (1896). What is Republicanism?. The Open Court, 18(453), 4897-4899

Cope, E.D. (1904). The primary factors of organic evolution. London: Open Court.

Cope, E.D., Packard, A.S. (1886). Editors' Table. The American Naturalist, 8(20), 708-710.

Cope, E.D. (1868). On the Origin of Genera. Proceedings of the Academy of Natural Sciences, 20, 242-300.

Darwin Correspondence Project. (1871). Letter no. 8039. (https://www.darwin project.ac.uk/letter/DCP-LETT-8039.xml), [dostęp 2021/08/24].

Darwin Correspondence Project. (1872). Letter no. 8551. (https://www.darwinpro ject.ac.uk/letter/DCP-LETT-8551.xml), [dostęp 2021/08/24].

Darwin, K. (1959). Dzieta Wybrane. Tom II. O powstawaniu gatunków droga doboru naturalnego, czyli o utrzymywaniu się doskonalszych ras w walce o byt. Warszawa: Państwowe Wydawnictwo Rolnicze i Leśne.

Davidson, J.P. (1997). The Bone Sharp: The Life of Edward Drinker Cope. Philadelphia: The Academy of Natural Sciences of Philadelphia. 
Gray, A. (1893). To Charles Darwin. Cambridge, March 7, 1872. W: J.L. Gray (red.), Letters of Asa Gray. In Two Volumes. Vol. II, 623-624. Boston, New York: Houghton, Mifflin and Company.

Hagen, E.H. (2005). Controversial Issues in Evolutionary Psychology. W: D.M. Buss (red.), The handbook of evolutionary psychology, 145-173. New Jersey: John Wiley and Sons.

Hall, B.K. (2002). Paleontology and evolutionary developmental biology: a science of the nineteenth and twenty-first centuries. Paleontology, 2(45), 647-669.

Hering, E. (1913). Memory. Lectures on the specific energies of the nervous systems. Chicago - London: Open Court.

Hilton, E.J., Mitchell, J.C., Smith, D.G. (2014). Edward Drinker Cope (18401897): Naturalist, Namesake, Icon. Copeia, 4, 747-761.

Hyatt, A. (1884). Cycle in the life of the individual (ontogeny) and in the evolution of its own group (phylogeny). Science, 5(109), 161-171.

Jonason, P.K., Schmitt, D.P. (2016). Quantifying Common Criticisms of Evolutionary Psychology. Evolutionary Psychological Science, 2, 177-188.

Mayer, A.G. (1911). Alpheus Hyatt, 1838-1902. Popular Science Monthly, 78, 133.

Mayr, E. (1982). The growth of biological thought. Diversity, evolution and inheritance. Cambridge - London: The Belknap Press of Harvard University Press.

Moore, J.R. (1979). The Post-Darwinian Controversies. A study of the Protestant struggle to come to terms with Darwin in Great Britain and America 1870-1900. Cambridge: Cambridge University Press.

Noguera-Solano, R. (2013).The metaphor of the architect in Darwin: Chance and free will. Zygon, 4(48), 859-874.

Osborn, H.F. (1929). Biographical Memoir of Edward Dinker Cope 1840-1897. Biographical Memoirs, 13, 127-317.

Packard, A.S. (1901). Lamarck The founder of evolution. His Life and Work. London - Bombay: Longman, Green and Co.

Packard, A.S. (1898). A half-century of evolution, with special reference to the effects of geological changes on animal life. The American Naturalist, 32(381), 623-674.

Paley, W. (1852). Paley's Natural Theology and Horae Pauline. New York: American Tract Society.

Popławski, B. (2007). Recepcja darwinizmu w Królestwie Polskim. „Głos” (18861894). Przeglad Humanistyczny, 2, 97-114.

Popowicz, K. (2009). Lamarkizm spoteczny a rasizm i eugenika we Francji. Warszawa: Wydawnictwo Uniwersytetu Warszawskiego. 
Rainger, R. (2009). Paleontology. W: P.J. Bowler, J.V. Pickstone (red.), The Cambridge History of Science. Vol. 6: The Modern Biological and Earth Sciences, 185-204. New York: Cambridge University Press.

Wilson, D.S., Dietrich, E., Clark, A.B. (2002). On the inappropriate use of the naturalistic fallacy in evolutionary psychology. Biology and Philosophy, 18, 669-682.

Z. (1872). Zoology: Error in Darwin's 'Origin in Species'. The American Naturalist, 6(5), 307-308. (http://www.jstor.org/stable/2463759), [dostęp 2021/08/24].

\section{EDWARD D. COPE'S PROJECT OF EVOLUTIONARY “THEOLOGY"}

Abstract. Edward Dinker Cope (1840-1897) was one of the most influential naturalists of the nineteenth century, who led the development of American paleontology and the popularization of Lamarck's theory of evolution. One of the overlooked threads in his biography is his philosophical views. According to Cope, theology should be reformed with the introduction of new philosophical assumptions in line with the emerging theory of evolution. Cope proposed the formulation of a new "theology" based on his own theory of evolution. This article examines Cope's philosophical views and shows how he reinterpreted the mechanism of natural selection by incorporating it into his own teleological account of evolution. According to Cope free will enables man to control evolution, but there is no guarantee that man will survive. According to Cope, this is a theological thesis as he considers maladaptation as equivalent to sin, which in turn was eliminated by natural selection. As a result, belief in God becomes the only way to guarantee survival. However, this conclusion also led Cope to rationalize racism as he saw in the exploitation of other races the effects of their degeneration. Cope's views reflect problems in contemporary sociobiology and evolutionary psychology.

Keywords: Edward Dinker Cope; evolution; Charles Darwin; neo-Lamarckism; eclipse of Darwinism

\section{MICHAŁ WAGNER}

Uniwersytet Kardynała Stefana Wyszyńskiego w Warszawie, Instytut Filozofii (Cardinal Stefan Wyszyński University in Warsaw, Institute of Philosophy, Poland) ORCID https://orcid.org/0000-0002-2912-9743

m.wagner@uksw.edu.pl

DOI 10.21697/spch.2021.57.A.11

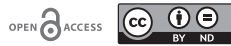
Tekst jest udostępniany na zasadach licencji Creative Commons (CC BY-ND 4.0 Międzynarodowe). Zgłoszono: 29/08/2021. Zrecenzowano: 11/10/2021. Zaakceptowano do publikacji: 25/10/2021. 